Arch. histol. jap. Vol. 22, n. 1 (August 1961).

P. 37-52.

2nd Dept. of Anat., Wakayama Med. College (Prof. K. FUJIE).

\title{
Studies on the Secretory Activity of the Gastric Peptic Cells and the Pancreatic Cells in Vitro. \\ I. The Preservation and the Promotion of the Secretory Activity in Vitro.
}

生体外に於け万胃腺主細胞，萃細胞の分泌機能に関する研究.

I. 生体外に於ける分泌機能の保持とその促進について.

\author{
Kimio FUJIE, Kazuo SUGIMOTO, Shuichiro SHIMAKURA \\ and Junji HATANAKA \\ 藤江: 君夫, 杉本和男, 嶋倉周一郎, 畑中淳治.
}

(Received August 1, 1961.)

The productin theory of FUJIE (1952) is based on the following facts that 1. the vacuoles which are seen in the subnuclear portion of the gastric surface cells decrease after administration of the diet, 2. the production of secretory granules in the gastric peptic cells (chief cells) and the pancreatic cells is promoted when the vacuoles mentioned above decrease, 3. the production of the secretory granules in the gastric peptic and the pancreatic cells is initiated in the rats which before being fed are injected with the blood obtained from the other rats $\frac{1}{2}-1 \mathrm{hr}$. after diet has been administered to them, 4. these same results are obtained if the HCl-extract of the hog's stomach is injected into rats which are still unfed, 5. the production of the secretory granules in the gastric peptic and the pancreatic cells is initiated actively after the subcutaneous injection of histamine solution $(0.3 \%)$ and 5 . an imidazol group is proved to exist in the subnuclear portion of the gastric surface cells by the using chemical colour reactions according to the histochemical method. His theory is supported by various investigations made by his collaborators.

The fact that histamine promotes the production of secretory granules in the gastric peptic and the pancreatic cells is proved by the subcutaneous injection of histamine solution and by injecting it into the stomach. The effect of histamine seems to be due to the direct action of histamine on the cells haematogenously, but it is not yet established as certain.

The authors have attempted to test if the effect of histamine on the gastric peptic and the pancreatic cells in vitro is similar to that obtained in vivo, in order to ascertain whether the effect is caused by histamine itself or not.

\section{Materials and Methods.}

The experimental animals are adult and male rats weighting $100-120 \mathrm{gm}$. They were accustomed to regular feeding of McCOLLUM's artificial diet for more than a 
week prior to the experiments.

Experiment I.

1. The stomach and the pancreas were taken from the rats which are still unfed ( $24 \mathrm{hrs}$. after the last diet), and they were placed at once in the fixation-liquid.

2. The stomach and the pancreas obtained as in no. 1. were placed in $37^{\circ} \mathrm{C}$ TYRODE's liquid (described below as T. Y.) for $\frac{1}{2}, 1,2,3,6 \mathrm{hrs}$. respectively, and afterwards transferred to the fixation-liquid.

3. The stomach and the pancreas were taken from the rats $1 \mathrm{hr}$. after diet was administered, and some were placed at once in the fixation-liquid as in no. 1 and the others were placed in T. Y. and then in the fixation-liquid as in no. 2.

4. The stomach and the pancreas of the rats which before being fed are injected with $0.3 \%$ histamine $\cdot 2 \mathrm{HCl}$ solution, were removed $1 \mathrm{hr}$. after the injection. They were placed in T. Y. and then in the fixation-liquid as in no. 2.

5. The stomach and the pancreas obtained from the rats which are still unfed were placed in T. Y. containing histamine $\cdot 2 \mathrm{HCl}$ in $0.3 \%$ (described below as $0.3 \%$ H. T. Y.) for $\frac{1}{2}, 1,2,3,6 \mathrm{hrs}$. respectively and then placed in the fixation-liquid.

Experiment II.

The stomach and the pancreas obtained from the rats which are still unfed were placed in the T. Y. containing histamine $2 \mathrm{HCl}$ in the rate of $0.2,0.1,0.05,0.03$ and $0.01 \%$. After $\frac{1}{2}, 1$ and 2 hrs. they were placed in the fixation-liquid.

To obtain materials in both Experiment I and II, under deep ether narcosis the abdomen was opened and the stomach and the pancreas were taken out. For the fixation of the materials, ZENKER's and KOLSTER's liquid were used. Paraffin sections of $7 \mu$ were made from the materials fixed by ZENKER's liquid and they were stained by hematoxylin-eosin for general histological observation. The materials fixed by KOLSTER's liquid were made into the serial paraffin sections of $4 \mu$ and these were stained by HEIDENHAIN's iron hematoxylin for cytological observation.

\section{Observations and Discussion.}

Here, we take stock of our observations on the gastric peptic cells, the gastric surface cells and the pancreatic cells. With regard to the gastric peptic cells, we describe 1. the quantity of secretory granules and vacuoles, 2. the form of plastosomes (pls.)etc. When the upper half of the cell body was full of the granules or vacuoles, it was marked +++ , when no granules or vacuoles were seen it was marked - (Fig. 1 ), and between +++ and - three intervening grades of,,+++ \pm were used.

In the surface cells of the gastric mucous membrane, the quantity of productin vacuoles (FUJIE) was marked +++ when the vacuoles filled up the lower half of the cell body and marked ++++ when they were more numerous, and was marked - when no vacuoles could be seen. And three intervening steps of,+++ and \pm were suitably selected between +++ and - (Fig. 2 ).

In the pancreatic cells, 1 . the quantity of zymogen granules $(+++,++,+$, \pm , - , as shown in Fig. 3), 2. the distribution of the granules (dense, less dense, sparse), 3. the irregularity in the size of the granules (remarkable, less remarkable, negligible), 4. the form of pls. and 5. the aspect of the gland lumen (empty, scattered, 
massed, replete as shown in Fig. 4) are described.

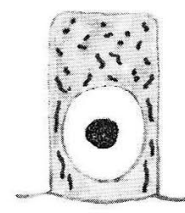

$(-)$

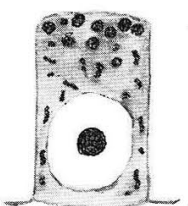

$( \pm)$

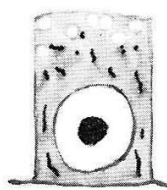

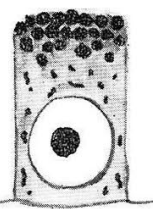

$(+)$

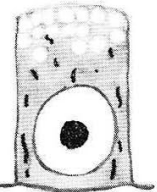

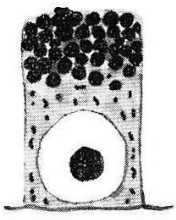

$(++)$

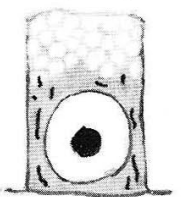

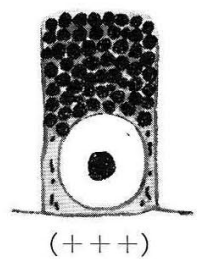

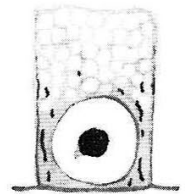

Fig. 1. The standard diagrams to determine the quantity of secretory granules and vacuoles in the peptic cells.

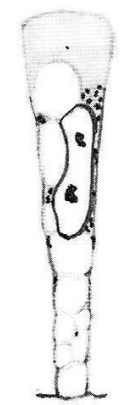

$(+++)(+++)$

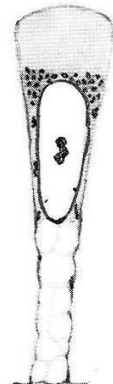

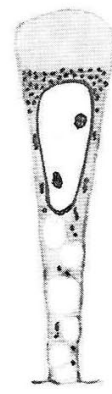

$(++)$

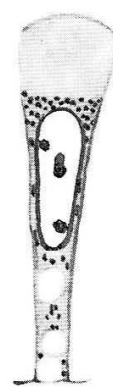

$(+)$

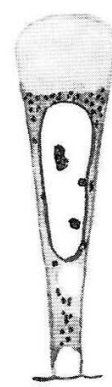

(士)
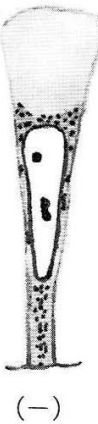

Fig. 2. The standard diagrams represented the quantity of productin vacuoles in the gastric surface cells.

Gland lumen Centroacinous cell

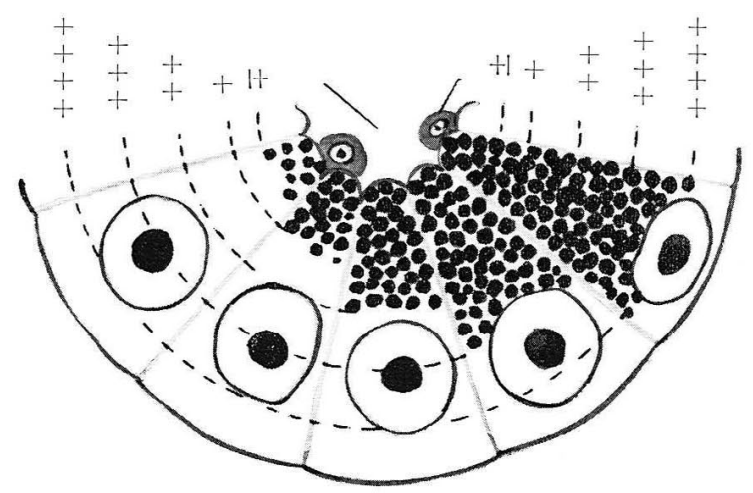

Fig. 3. Diagram on the content of zymogen granules in the pancreatic cells. 


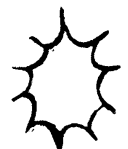

empty

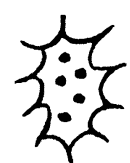

scattered

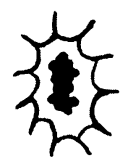

massed

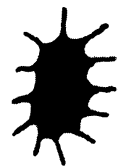

replete

Fig. 4. Standard figures on the aspect of the pancreatic gland lumen.

\section{A. Results obtained from Experiment I.}

The results obtained from the gastric peptic cells, the gastric surface cells and the pancreatic cells are tabulated in Table 1, 2 and 3.

Table 1. The gastric peptic cells of Experiment I.

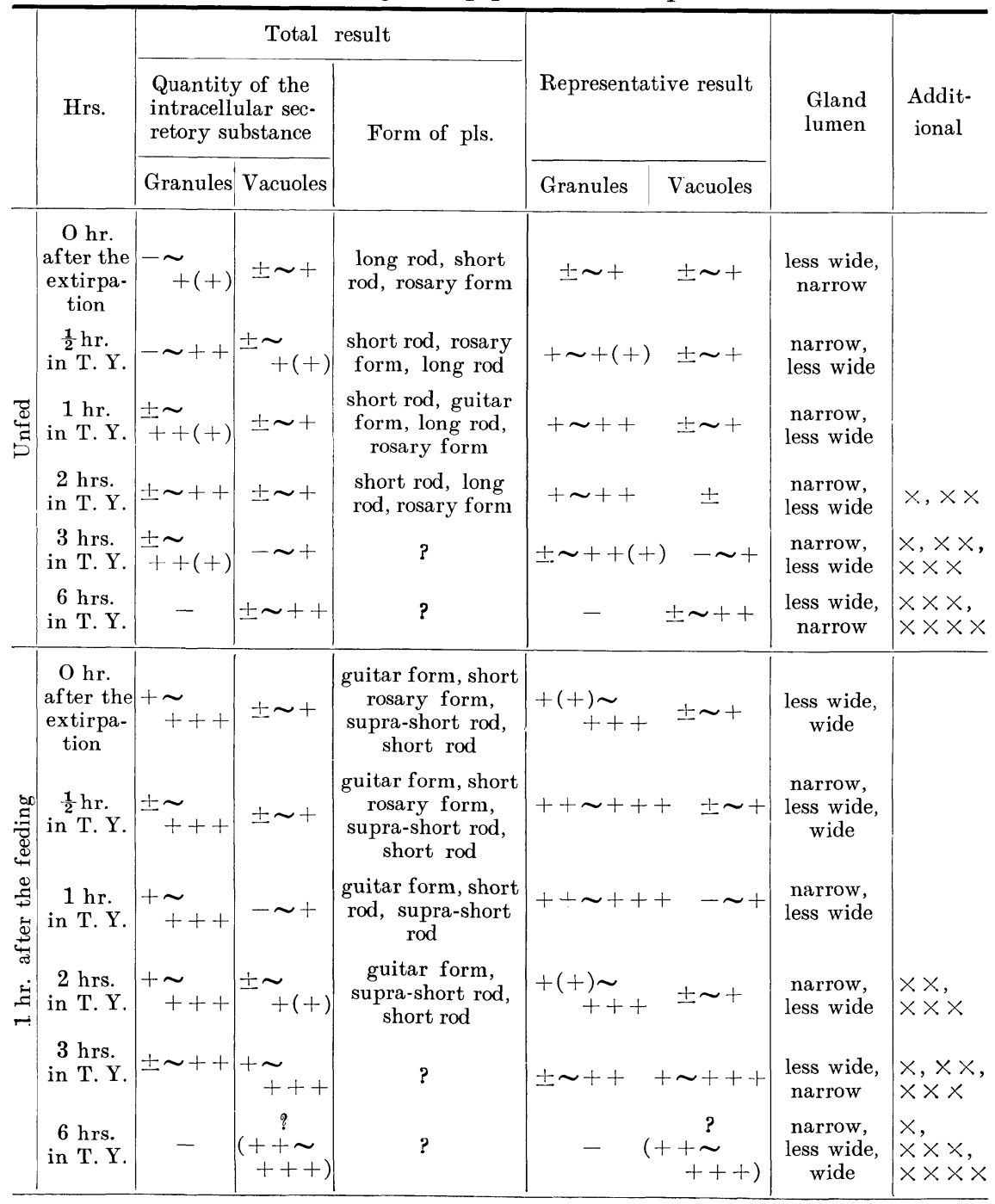




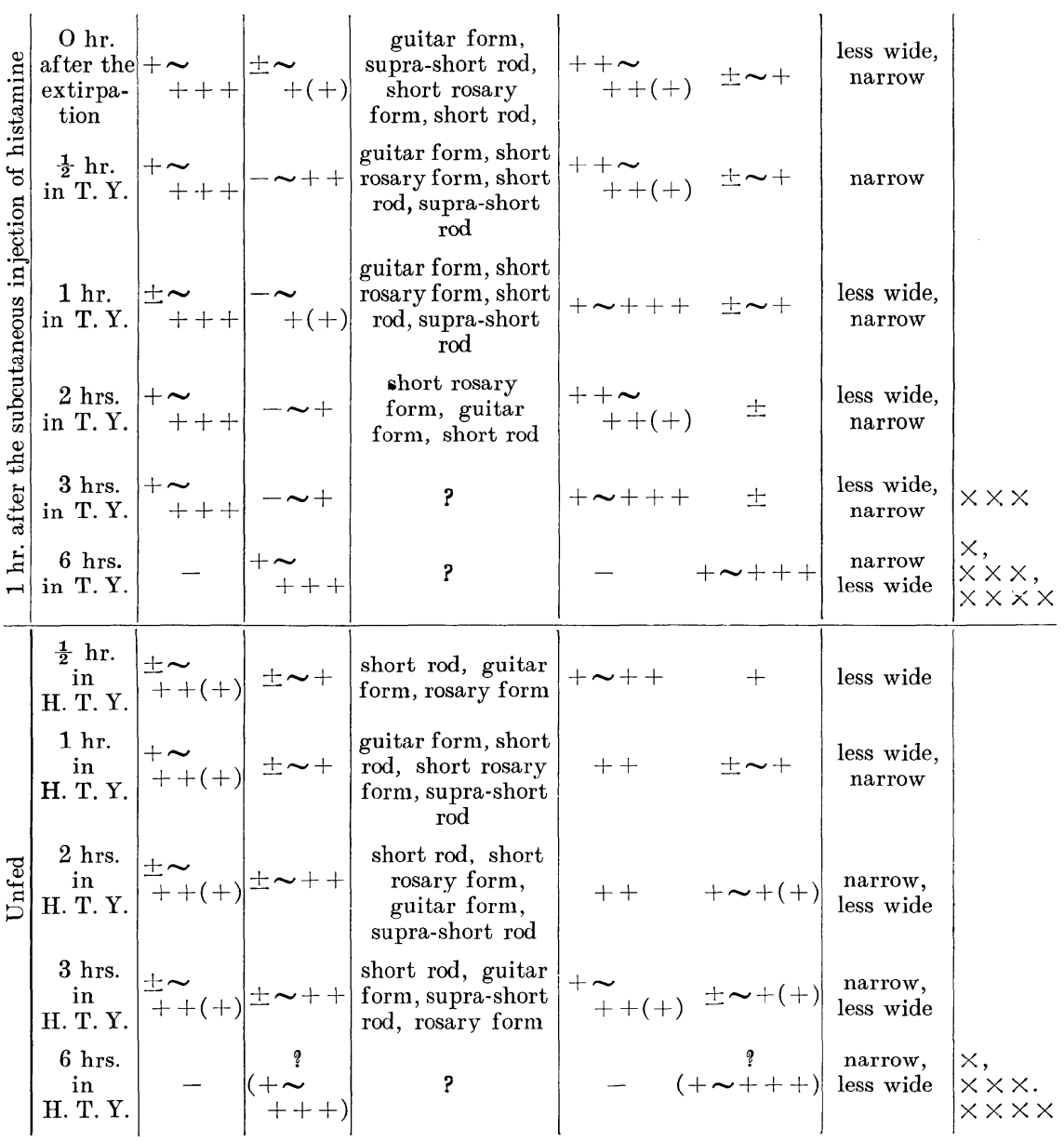

Notes: $\times$ A low stainability of secretory granules in the cell. $\times \times$ A low stainability of plastosomes. $\times \times \times$ Form of degenerative plastosomes; giant granule, droplet form, racket form, comma form, beer barrel form etc. $\times \times \times \times$ Degeneration of the cell; secretory granules and plastosomes are not stained, pycnosis or atrophy of the nucleus is seen.

Table 2. Productin vacuoles in the gastric surface cells of Experiment I.

\begin{tabular}{|c|c|c|c|}
\hline & \multirow{2}{*}{ Hrs. } & \multicolumn{2}{|c|}{$\begin{array}{c}\text { Quantity of productin vacuoles } \\
\text { in the surface cells }\end{array}$} \\
\hline & & Total result & $\begin{array}{l}\text { Representative } \\
\text { result }\end{array}$ \\
\hline$\underset{⿱ 乛 ⿻}{\Phi}$ & $\begin{array}{l}\mathrm{O} \text { hr. after the extirpation } \\
\frac{1}{2} \mathrm{hr} . \text { in T. Y. } \\
1 \mathrm{hr} . \text { in T. Y. } \\
2 \mathrm{hrs} . \text { in T. Y. }\end{array}$ & $\begin{array}{l}+\sim+++ \\
-\sim++(+) \\
-\sim++(+) \\
\pm \sim+++\end{array}$ & $\begin{array}{l}+\sim+++ \\
\pm \sim++ \\
\pm \sim++ \\
+\sim++\end{array}$ \\
\hline
\end{tabular}




\begin{tabular}{|c|c|c|c|}
\hline & $\begin{array}{l}3 \text { hrs. in T. Y. } \\
6 \text { hrs. in T. Y. }\end{array}$ & $\begin{array}{l} \pm \sim+++ \\
\pm \sim+++(?)\end{array}$ & $\begin{array}{l}+\sim++ \\
\pm \sim++(?)\end{array}$ \\
\hline 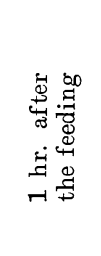 & $\begin{array}{l}\mathrm{O} \text { hr. after the extirpation } \\
\frac{1}{2} \mathrm{hr} . \text { in T. Y. } \\
1 . \mathrm{hr} . \text { in T. Y. } \\
2 \mathrm{hrs.} \text { in T. Y. } \\
3 \mathrm{hrs.} \text { in T. Y. } \\
6 \mathrm{hrs.} \text { in T. Y. }\end{array}$ & $\begin{array}{l}-\sim++ \\
-\sim++ \\
-\sim++(+) \\
-\sim++(+) \\
-\sim++ \\
-\sim++(+)\end{array}$ & $\begin{array}{l}-\sim+(+) \\
\pm \sim+(+) \\
-\sim++ \\
-\sim++ \\
-\sim++ \\
-\sim++(?)\end{array}$ \\
\hline 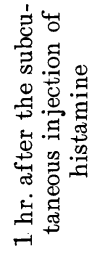 & $\begin{array}{l}\mathrm{O} \text { hr. after the extirpation } \\
\frac{1}{2} \mathrm{hr} . \text { in T. Y. } \\
1 \mathrm{hr} . \text { in T. Y. } \\
2 \mathrm{hrs.} \text { in T. Y. } \\
3 \mathrm{hrs.} \text { in T. Y. } \\
6 \mathrm{hrs.} \text { in T. Y. }\end{array}$ & $\begin{array}{l} \pm \sim+++ \\
\pm \sim+++ \\
\pm \sim+++ \\
+\sim+++ \\
+\sim+++ \\
+\sim+++\end{array}$ & $\begin{array}{l}+\sim+++ \\
+\sim+++ \\
+\sim+++ \\
+(+) \sim+++ \\
+\sim+++ \\
+\sim+++\end{array}$ \\
\hline 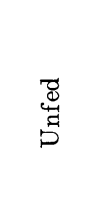 & $\begin{array}{l}\frac{1}{2} \mathrm{hr} . \text { in H. T. Y. } \\
1 \mathrm{hr} . \text { in H. T. Y. } \\
2 \mathrm{hrs.} \text { in H. T. Y. } \\
3 \mathrm{hrs.} \text { in H. T. Y. } \\
6 \mathrm{hrs.} \text { in H. T. Y. }\end{array}$ & $\begin{array}{l}-\sim+++ \\
\pm \sim+++(+) \\
\pm \sim+++ \\
\pm \sim+++(+) \\
+\sim+++\end{array}$ & $\begin{array}{l}+\sim+++ \\
+\sim+++ \\
+\sim+++ \\
+\sim+++ \\
+\sim+++(?)\end{array}$ \\
\hline
\end{tabular}

Table 3. The pancreatic cells of Experiment I.

\begin{tabular}{|c|c|c|c|c|c|c|}
\hline & \multirow{2}{*}{ Hrs. } & \multicolumn{3}{|c|}{ Zymogen granules } & \multirow{2}{*}{ Form of pls. } & \multirow{2}{*}{ Gland lumen } \\
\hline & & Quantity & $\begin{array}{l}\text { Distribu- } \\
\text { tion }\end{array}$ & $\begin{array}{l}\text { Irregularity } \\
\text { in size }\end{array}$ & & \\
\hline \multirow{8}{*}{ 总 } & $\begin{array}{l}\mathrm{O} \text { hr. } \\
\text { after the } \\
\text { extirpation }\end{array}$ & $+\sim+++$ & sparse & negligible & $\begin{array}{l}\text { long rod, } \\
\text { short rod }\end{array}$ & $\begin{array}{l}\text { empty, } \\
\text { scattered }\end{array}$ \\
\hline & $\begin{array}{l}\frac{1}{2} \mathrm{hr} . \\
\text { in T. Y. }\end{array}$ & $\underset{*}{+} \sim+++$ & sparse & negligible & $\begin{array}{l}\text { long rod, } \\
\text { short rod }\end{array}$ & $\begin{array}{l}\text { empty, } \\
\text { scattered }\end{array}$ \\
\hline & $\begin{array}{c}1 \mathrm{hr} . \\
\text { in } \mathrm{T} . \mathrm{Y} .\end{array}$ & $\underset{*}{+} \sim+++$ & $\begin{array}{c}\text { sparse } \\
\mid \\
\text { less dense }\end{array}$ & $\begin{array}{c}\text { negligible } \\
\text { less remarkable }\end{array}$ & $\begin{array}{l}\text { long rod, } \\
\text { short rod, } \\
* *\end{array}$ & $\begin{array}{l}\text { empty, } \\
\text { scattered }\end{array}$ \\
\hline & $\begin{array}{l}2 \mathrm{hrs} \text {. } \\
\text { in T. Y. }\end{array}$ & $\underset{*}{+} \sim+++$ & $\begin{array}{c}\stackrel{\text { sparse }}{\mid} \\
\text { less dense }\end{array}$ & $\begin{array}{c}\text { negligible } \\
\text { (less remarkable) }\end{array}$ & $\begin{array}{l}\text { long rod, } \\
\text { short rod, } \\
* *\end{array}$ & $\begin{array}{l}\text { empty, } \\
\text { scattered }\end{array}$ \\
\hline & $\begin{array}{l}3 \text { hrs. } \\
\text { in T. Y. }\end{array}$ & $\underset{*}{+} \sim+++$ & $\begin{array}{c}\text { sparse } \\
\mid \\
\text { less dense }\end{array}$ & negligible & $\begin{array}{l}\text { long rod, } \\
\text { short rod, } \\
* *\end{array}$ & $\begin{array}{l}\text { empty, } \\
\text { scattered } \\
\text { (massed) }\end{array}$ \\
\hline & $\begin{array}{l}6 \text { hrs. } \\
\text { in T. Y. }\end{array}$ & $\underset{*}{+} \sim+++$ & less dense & $\begin{array}{c}\text { negligible } \\
\text { less remarkable }\end{array}$ & $?$ & $\begin{array}{l}\text { empty, } \\
\text { scattered }\end{array}$ \\
\hline & $\begin{array}{c}\mathrm{O} \text { hr. } \\
\text { after the } \\
\text { extirpation }\end{array}$ & $\begin{array}{l}++\sim \\
+++(+)\end{array}$ & less dense & $\begin{array}{c}\text { less remarkable } \\
\text { negligible }\end{array}$ & $\begin{array}{c}\text { guitar form, } \\
\text { short rosary } \\
\text { form, short rod }\end{array}$ & $\begin{array}{l}\text { scattered, } \\
\text { empty, } \\
\text { massed, } \\
\text { replete }\end{array}$ \\
\hline & $\begin{array}{l}\frac{1}{2} \mathrm{hr} . \\
\text { in T. Y. }\end{array}$ & ${ }_{*}^{+} \underset{+}{\sim}+(+)$ & less dense & $\begin{array}{c}\text { less remarkable } \\
\text { negligible }\end{array}$ & $\begin{array}{l}\text { guitar form, short } \\
\text { rod, rosary form, } \\
* *\end{array}$ & $\begin{array}{l}\text { empty, } \\
\text { scattered }\end{array}$ \\
\hline
\end{tabular}




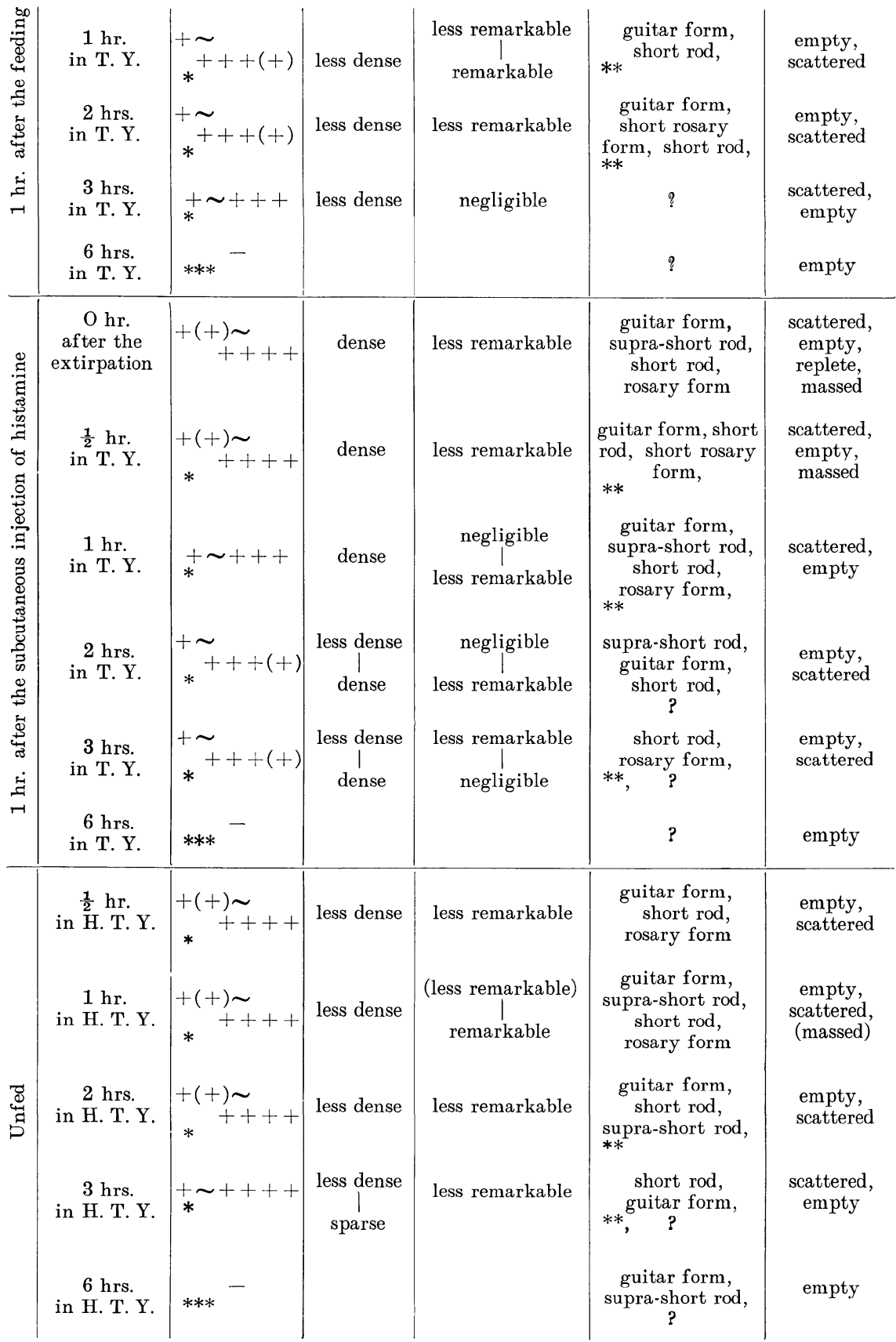

Notes: * As is shown in Fig. 5, the big vacuoles are seen to be within zymogen granules zone. It seems to be a section of the massed zymogen granules which 


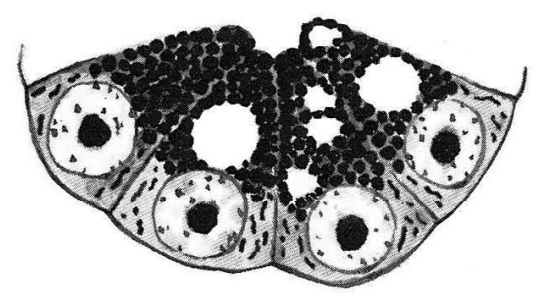

Fig. 5. A degenerative figure in zymogen granules zone of the pancreatic cells.

have lost their quality of stainability. ** Form of degenerative plastosomes; giant granule, droplet form, ring form, racket form, comma form, beer barrel form, irregular form etc. ? Majority of plastosomes lose their stainability. Consequently, only a few plastosomes can be seen. *** Degeneration of the pancreatic cells; the zymogen granules zone contains vacuoles, the exert of which is not clearly determined, pycnosis and atrophy can be seen in the nucleus.

\section{B. Discussion on the results of Experiment $\mathrm{I}$.}

With a view to organ preservation, KASAMATSU has previously studied from the surgical standpoint the plastosomes of the cells in vitro preserved in the various medium. According to his observations, the cells were preserved for long period in TYRODE's liquid. This is the reason why the authors have used TYRODE's liquid (T. Y.).

The gastric peptic cells of the stomach $24 \mathrm{hrs}$. after the diet was given (cf. Table 1 ), have an extremely low activity on the production and the discharge of secretory granules. In T. Y., secretory granules increase a little in the cells and plastosomes show a little active transformation. But $2 \mathrm{hrs}$. later some of plastosomes begin to show degenerative form, and 6 hrs. later the cells lose their normal structure.

On the other hand, the gastric surface cells of the same stomach immersed in T. Y., discharge some productin vacuoles from the cells. $2 \mathrm{hrs}$. later the degenerative cells increase. An explanation of the reason why productin vacuoles are discharged in T. Y. is not yet available, however the period when secretory granules in the peptic cells are increasing corresponds to the period when the productin vacuoles in the surface cells are decreasing. The capillary vessels of the lymph and veins in the mucous membrane of the stomach arise from the subepithelial region and form the plexus surrounding the base of the gastric glands. If, when the stomach is placed in T. Y., productin is discharged from the gastric surface cells and if the peptic cells are living, then the productin discharged ought to produce an increase of secretory granules in the peptic cells.

From these results, it is presumed that the gastric peptic cells in vitro have still power to activate secretory activity.

The stomach obtained from the rats $1 \mathrm{hr}$. after the feeding and $1 \mathrm{hr}$. after the subcutaneous injection of histamine $\cdot 2 \mathrm{HCl}$ proves, in vitro, that the gastric peptic cells still retain their active form (i. e. secretory function) not only when placed in the fixation-liquid but even when placed in T. Y. until the time when the cells begin 
to degenerate (cf. Table 1). If it is in vivo, the production of secretory granules decreases gradually thereafter and the discharge (vacuolization) of them increases in the peptic cells, and the productin vacuoles which decreased temporarily after the diet was given increase thereafter in the gastric surface cells. In vitro, the productin which was secreted from the gastric surface cells and reached the gastric glands, or the histamine which was injected and reached there, will remain without decomposing and will act as a stimulant on the peptic cells, because there is no circulation of the blood. On the other hand, the gastric surface cells do not produce further the productin vacuoles after the discharge of them resulting from the feeding, because there is no materials to compose the productin in $\mathrm{T}$. $\mathrm{Y}$.

The results obtained from the stomach $1 \mathrm{hr}$. after the feeding and $1 \mathrm{hr}$. after the subcutaneous injection of histamine prove also that the gastric peptic cells may perform the secretory activity in vitro (in T. Y.). Therefore, it is considered that the secretory activity of the gastric peptic cells may be promoted artificially in T. Y. The authors attempted to add histamine $\cdot 2 \mathrm{HCl}$ to $\mathrm{T}$. $\mathrm{Y}$. in the same rate as that used usually by FUJIE when it is injected subcutaneously (0.3\%), and to observe the gastric peptic cells in the Histamine-TYRODE's liquid (H. T. Y.). In this case, secretory granules in the peptic cells increase positively during $\frac{1}{2}$ and $1 \mathrm{hr}$. in H. T. Y. and plastosomes show active transformation, i. e. the production of secretory granules is plainly visible. No discharge of productin vacuoles from the gastric surface cells is seen. These results are the same as those when $0.3 \%$ histamine solution is injected subcutaneously.

As mentioned previously, the peptic cells of the stomach of unfed rats produce secretory granules a little in T. Y., and the surface cells discharge some of productin vacuoles. The production of secretory granules in the peptic cells in H. T. Y. is too active to be compared with that in T. Y. However no discharge of productin vacuoles is seen in H. T. Y. Thus the results obtained from the peptic cells in H. T. Y. are believed to be due solely to the histamine added to T. Y. Comparing the peptic cells $1 \mathrm{hr}$. in H. T. Y. and the cells $1 \mathrm{hr}$. after the subcutaneous injection of histamine, the quantity of peptic secretory granules and the transformation of plastosomes in the cells are almost identical in each case. This comparison gives further proof of the peculiar activity of histamine in T. Y.

On the other hand, it is noticed that the degeneration of the peptic cells in vitro (in T. Y.) is delayed when histamine was injected subcutaneously prior to the extirpation of the stomach or when histamine was added to T. Y.

Thus the noticeable results which are obtainable from Table 1 may be summarized as follows: 1 . The peptic cells of the extirpated stomach retain for a long period in $37^{\circ} \mathrm{C} \mathrm{T}$. Y. an active function resulting in secretory activity; 2 . The active production of secretory granules can be seen in the peptic cells if histamine is added to $\mathrm{T}$. Y. at the rate of $0.3 \%$. This condition is very similar to that resulting from the subcutaneous injection of $0.3 \%$ histamine solution into the animals; 3 . The discharge of the peptic secretory granules from the cells (it is confirmed by FUJIE to be promoted by the decomposed product of histamine) is not seen in T. Y.; 4. Histamine can delay the degeneration of the peptic cells in vitro.

The pancreatic cells (cf. Table 3) in T. Y. have degenerative form of varied ex- 
tent, i. e. vacuolization (loss of stainability) of massed zymogen granules and the abnormal transformation of pls. The degenerative pls. appear more speedily in the pancreatic cells than in the peptic cells.

In the pancreas of unfed rats when it is placed in T. Y., neither production nor discharge of zymogen granules are ever caused in the pancreatic cells. In the case of the stomach of unfed rats, a less remarkable production in the peptic cells (cf. Table 1) and a slight discharge of productin vacuoles in the surface cells (cf. Table 2) were seen in T. Y. and the former may have been caused by the latter. In vitro, even if productin is discharged from the gastric surface cells and even if the productin is active in producing secretory granules in the peptic cells of the same stomach, the productin, however, can not have any effect on the pancreatic cells. Therefore these findings in the case of the pancreatic cells may be regarded as certain.

$1 \mathrm{hr}$. after feeding, both production and discharge of zymogen granules are remarkably active in the pancreatic cells. In the pancreas, placed in T. Y., the production of zymogen granules soon lessens and is almost negligible after $3 \mathrm{hrs}$., the discharge of these decreasing speedily. These results may be produced by a lack of stimulus on the secretory activity of the cell, and a proceeding degeneration of the cell.

However, in the pancreas placed in $0.3 \% \mathrm{H}$. T. Y. during a period of $\frac{1}{2}-1 \mathrm{hr}$. following, a marked production of zymogen granules can be observed in the pancreatic cells, but after that time the production decreases and the degenerative pls. increase. No discharge of zymogen granules is seen. Comparing the pancreatic cells after being placed for $1 \mathrm{hr}$. in the H. T. Y., and the cells $1 \mathrm{hr}$. after the subcutaneous injection of histamine, production of zymogen granules is almost identical in each case. However, discharge of these zymogen granules is visible in the latter case, and the degenerative cells are visible in the former case. In the case of the subcutaneous injection of histamine, i. e. the case in vivo, the effect of the duodenal hormone secretin may be presumed, the discharge of zymogen granules will result from it, but in the case of H. T. Y., i. e. in vitro, it is not so, as is proved in the above comparison.

From these results obtained from the pancreatic cells (cf. Table 3), it may be noticed that 1 . the pancreatic cells are liable to degenerate in vitro, 2. production of zymogen granules is promoted by histamine both in vivo and in vitro.

\section{Results obtained from Experiment II.}

The observations of Experiment II are listed in Tables 4-6, in the same manner as was Experiment I.

\section{Discussion on the results of Experiment II.}

As proved in Experiment I, the production of secretory granules in the gastric peptic cells and the pancreatic cells is promoted by histamine added to $T$. Y. at the rate of $0.3 \%$. The authors then tested the effective rate of histamine-content in T. Y.

In the case of the gastric peptic cells (cf. Table 4), a noticeable increase of secretory granules in these cells, and a active transformation of pls. are seen when placed 
Table 4. The gastric peptic cells of Experiment II.

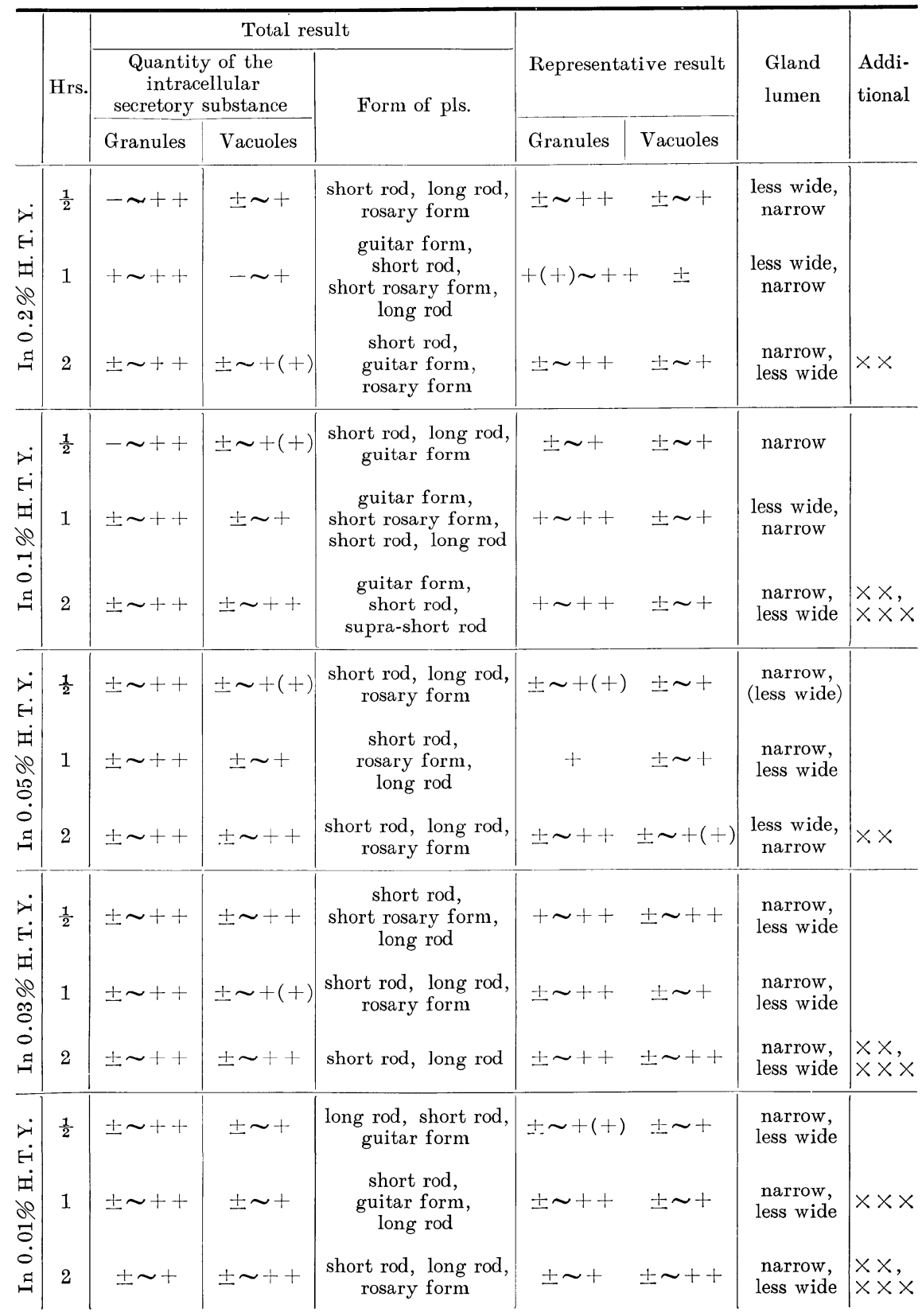

Notes: $\times x, \times \times \times$ Concerning these, confer explanation in Table 1 . 
Table 5. Productin vacuoles in the gastric surface cells of Experiment II.

\begin{tabular}{|c|c|c|c|c|c|c|c|}
\hline & & \multicolumn{2}{|c|}{$\begin{array}{l}\text { Quantity of productin vacuoles } \\
\text { in the surface cells }\end{array}$} & & & \multicolumn{2}{|c|}{$\begin{array}{l}\text { Quantity of productin vacuoles } \\
\text { in the surface cells }\end{array}$} \\
\hline & & Total result & $\begin{array}{l}\text { Representative } \\
\text { result }\end{array}$ & & & Total result & $\begin{array}{l}\text { Representative } \\
\text { result }\end{array}$ \\
\hline & $\frac{1}{2}$ & $+\sim+++$ & $+\sim+++$ & id & $\frac{1}{2}$ & $+\sim+++$ & $+\sim+t+$ \\
\hline$\stackrel{\sim}{0}$ & 1 & $+\sim+++$ & $+\sim+t+$ & ن. & 1 & $+\sim+t+$ & $+\sim+t+$ \\
\hline$\Xi \boxplus$ & 2 & $+\sim+++$ & $+\sim+++$ & تص & 2 & $+\sim+++$ & $+\sim+++$ \\
\hline$d e^{2}$ & $\frac{1}{2}$ & $+\sim+++$ & $+\sim+++$ & ن & $\frac{1}{2}$ & $+\sim+++$ & $+\sim+t+$ \\
\hline$\ddot{0}$ & 1 & $\pm \sim+++$ & $+\sim+++$ & نت & 1 & $+\sim+++$ & $+\sim+++$ \\
\hline$\Xi$ & 2 & $+\sim+++$ & $+\sim+++$ & نَ & 2 & $\pm \sim+++$ & $\pm \sim++(+)$ \\
\hline$d$ & $\frac{1}{2}$ & $+\sim+++$ & $+\sim+++$ & & & & \\
\hline تं & 1 & $+\sim+++$ & $+\sim+++$ & & & & \\
\hline$\nexists$ & 2 & $+\sim+++$ & $+\sim+++$ & & & & \\
\hline
\end{tabular}

Table 6. The pancreatic cells of Experiment II.

\begin{tabular}{|c|c|c|c|c|c|c|}
\hline & \multirow{2}{*}{ Hrs. } & \multicolumn{3}{|c|}{ Zymogen granules } & \multirow{2}{*}{ Form of pls. } & \multirow{2}{*}{ Gland lumen } \\
\hline & & Quantity & $\begin{array}{l}\text { Distribu- } \\
\text { tion }\end{array}$ & $\begin{array}{l}\text { Irregularity } \\
\text { in size }\end{array}$ & & \\
\hline 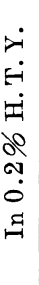 & $\frac{1}{2}$ & $\begin{array}{l}+\sim+++ \\
++\sim+++\end{array}$ & less dense & $\begin{array}{l}\text { remarkable } \\
\text { less remarkable } \\
\text { remarkable } \\
\text { less remarkable } \\
\text { less remarkable } \\
\text { remarkable }\end{array}$ & $\begin{array}{l}\text { short rod, rosary form, } \\
\text { guitar form, long rod, } \\
\text { short rod, guitar form, } \\
\text { rosary form, } \\
* * \text {, } \\
\text { short rod, guitar form, } \\
\text { rosary form, long rod, } \\
\text { s* }\end{array}$ & $\begin{array}{l}\text { empty, scattered, } \\
\text { (massed) } \\
\text { empty, scattered, } \\
\text { empty, scattered }\end{array}$ \\
\hline 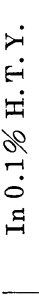 & $\frac{1}{2}$ & $\begin{array}{l}+\sim+++ \\
+\sim+++ \\
* \\
+(+) \sim+ \\
* \quad+++\end{array}$ & $\begin{array}{l}\text { less dense } \\
\text { less dense } \\
\text { sparse } \\
\text { less dense }\end{array}$ & $\begin{array}{c}\text { remarkable } \\
\text { less remarkable } \\
\text { remarkable } \\
\text { less remarkable } \\
\text { remarkable } \\
\end{array}$ & $\begin{array}{l}\text { short rod, short rosary } \\
\text { form, guitar form, } \\
\text { long rod, rosary form } \\
\text { short rod, short rosary } \\
\text { form, guitar form, } \\
\text { long rod, } \\
\text { ** } \\
\text { short rod, short rosary } \\
\text { form, long rod, } \\
\text { ** }\end{array}$ & $\begin{array}{l}\text { empty, scattered, } \\
\text { (massed) } \\
\text { empty, scattered, } \\
\text { massed } \\
\text { empty, scattered }\end{array}$ \\
\hline 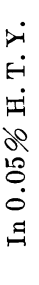 & $\frac{1}{2}$ & $\begin{array}{l}++\sim+++ \\
+(+) \sim \\
* \quad+++\end{array}$ & $\begin{array}{l}\text { less dense } \\
\text { less dense } \\
\text { sparse }\end{array}$ & $\begin{array}{c}\text { remarkable } \\
\text { less remarkable } \\
\text { remarkable } \\
\text { less remarkable } \\
\text { remarkable }\end{array}$ & 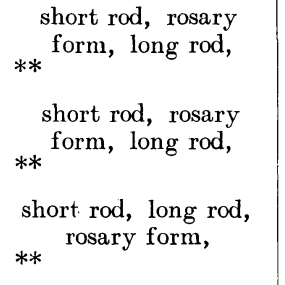 & $\begin{array}{l}\text { empty, scattered } \\
\text { empty, scattered, } \\
\text { massed } \\
\text { empty, scattered, } \\
\text { (massed) }\end{array}$ \\
\hline & $\frac{1}{2}$ & $\underset{*}{+} \sim+++$ & less dense & negligible & $\underset{* *}{\text { long rod, short rod, }}$ & empty, scattered \\
\hline
\end{tabular}




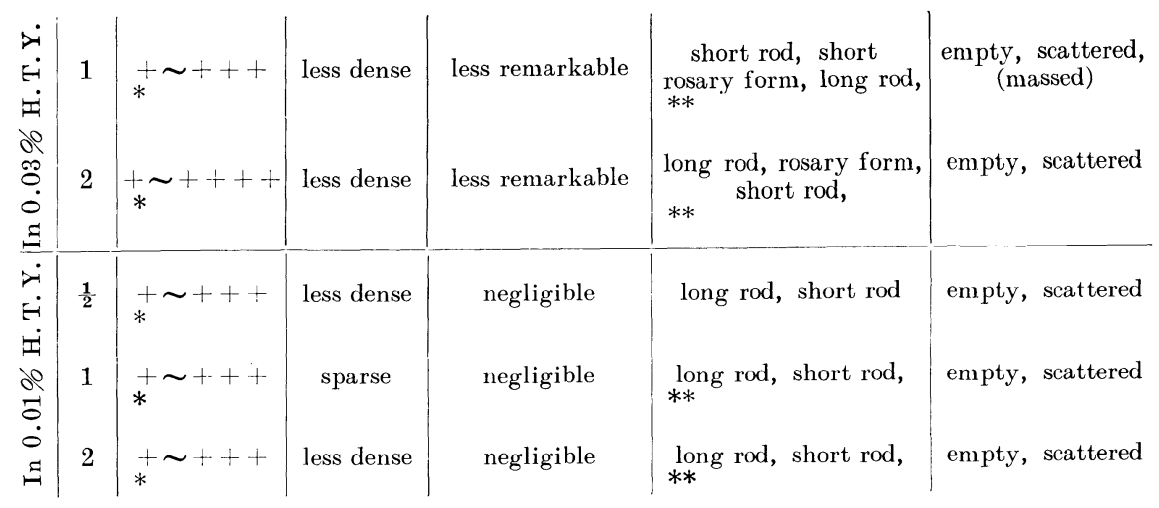

Notes: *, ** Concerning these, confer explanation in Table 3.

in 0.2 and $0.1 \%$ histamine-TYRODE's liquid (H. T. Y.), and these results are negligible on other strenghts of the same liquid (e. g. $0.05,0.03$ and $0.01 \%$ H. T. Y.). Comparing the cells placed in $0.2 \% \mathrm{H}$. 'T. Y. with those placed in $0.1 \% \mathrm{H}$. T. Y., the secretory activity seems to be less in the case of the latter. Comparing the cells in $0.2 \%$ H. T. Y. with those in $0.3 \%$ H. T. Y. (cf. Table 1), the increase of secretory granules in the cells is more marked in the case of $0.3 \%$ than in that of $0.2 \%$. On the other hand, it is noticed that the greater the increase in the content of histamine in T. Y., the more the transformation of the pls. in the cells becomes active. Degenerative pls. seem to increase speedily in T. Y. of low histamine-content $(0.05,0.03$ and $0.01 \%$ ).

Productin vacuoles in the gastric surface cells (cf. Table 5) do not increase or decrease in $\mathrm{H} . \mathrm{T}$. Y. regardless of the content of histamine.

The pancreas placed in $0.2 \% \mathrm{H}$. T. Y., during a period of $\frac{1}{2}-1 \mathrm{hr}$. following, an active production of zymogen granules is visible in the pancreatic cells (cf. Table 6). The production of zymogen granules is still visible even in $0.05 \% \mathrm{H}$. T. Y., though it is less active; however, it is negligible in 0.03 and $0.01 \% \mathrm{H}$. T. Y. It is noticed that the greater the increase in the content of histamine, the more active the production of zymogen granules becomes; that is, the production of zymogen granules is presumed to be promoted by histamine.

\section{Snmmary.}

It was proved previously that the subcutaneous injection of histamine causes the production of secretory granules in both the gastric peptic cells and the pancreatic cells. The authors here studied the effects of histamine on these cells of the stomach and the pancreas which were extirpated and preserved in vitro (i. e. in TYRODE's liquid). They did this in order to ascertain whether the above effects resulting from the histamine injection are definitely the effects of histamine itself or not.

From unfed rats, the authors extirpated the stomach and the pancreas. Some of these were placed immediately in the fixation-liquid (ZENKER's and KOLSTER's liquid) and the others in TYRODE's liquid $\left(37^{\circ} \mathrm{C}\right)$ for periods of $\frac{1}{2}, 1,2,3,6 \mathrm{hrs}$. 
The latter were then transferred to fixation-liquid. The stomach and the pancreas were also taken from rats $1 \mathrm{hr}$. after the diet was given, and also from rats $1 \mathrm{hr}$. after a subcutaneous injection of histamine. These two groups were treated in the same manner as noted above. Thus, the authors observed the activity of the secretory function in the peptic and pancreatic cells of the extirpated stomach and pancreas in vitro.

On the other hand, the stomach and the pancreas obtained from unfed rats were both placed in TYRODE's liquid containing histamine $2 \mathrm{HCl}$ in the rate of $0.3,0.2$, $0.1,0.05,0.03$ or $0.01 \%$. In this way, the authors observed that the secretory activity of the peptic and pancreatic cells was promoted artificially in vitro (i.e. in TYRODE's liquid).

The results obtained may be summarized as follows.

1. The gastric peptic cells of the extirpated stomach retain a secretory activity for a long period in TYRODE's liquid.

2. In TYRODE's liquid containing histamine, the production of secretory granules in the peptic cells is promoted. This promotion or activity differs according to the content of histamine. The graater the increase there is in the histamine content, the greater is the promotion or activity in the production of secretory granules in the peptic cells. This promotion holds good only in the case of $0.3-0.1 \% \mathrm{H}$. T. Y. The promotion is negligible in the case of $0.05-0.01 \% \mathrm{H}$. T. Y.

3. The physiological vacuolization of peptic secretory granules, which is a process of discharge of these granules, is not visible in TYRODE's liquid. A lack of stainability of the secretory granules is often sean when the peptic cells degenerate. This vacuolization, however, may have no connection to the discharge of the granules.

4. In TYRODE's liquid containing much histamine, the degeneration of the peptic cells in vitro is delayed.

5. The pancreatic cells of the extirpated pancreas degenerate in TYRODE's liquid more speedily than the peptic cells of the extirpated stomach.

6. In histamine-TYRODE's liquid, the production of zymogen granules is promoted in the pancreatic cells. This promotion is most marked in $0.3 \%$ histamineTYRODE's liquid and lowest in $0.05 \%$ H. T. Y. and negligible in 0.03 and $0.01 \%$ H. T. Y.

7. In TYRODE's liquid and in histamine-TYRODE's liquid, the discharge of zymogen granules is not caused.

8. From these results, it may be proved that the production of secretory granules in both the peptic cells and the pancreatic cells is promoted by histamine itself regardless whether it is in vivo or in vitro.

\section{内 容自 抄.}

生体にヒスタミンを皮下注射す石と胃腺主細胞及び膵細胞の分泌颗粘新生が促 進されることは既に明かであるので，著者等はこの效罢が真にヒスタミン自体に 由来す万のか否かを明らかにするために，生体外に摘出した筒及び膵を用いて冒 腺主細胞と膵細胞に対するヒスタミン㬵罢を检意せんとした。このため空腹垨の

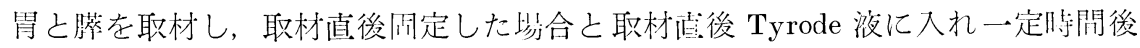


に圆定した場合を比較し，また給食 1 時間後，ヒスタミン皮下注射 1 時間後に夫 々取材してTyrode 液に入れて後に固定した場合を観察し, 生体外に於て胃腺主細 胞, 膵細胞の分泌機能営為能力が如何に保持されるかを検した 次でまた Tyrode 液中へ 0.3 乃至 $0.01 \%$ の割にヒスタミンを添加した各種濃度のヒスタミン-Tyrode 液中へ空腹時の胃と膵を入れ，胃腺主細胞及び膵細胞の分泌機能的活動を 観察した。得たる結果は以下の如く要約される。

1. 摘出した胃の胃腺主細胞は Tyrode 液中に於てかなり長く分泌機能営為能力 を保持している。

2. Tyrode 液中へヒスタミンを添加するとヒスタミン濃度によって胃腺主細胞 には明かな分泌顆粒新生が認められる。それは $0.3 \%$ ヒスタミンーTyrode 液中に て最も顕著で， $0.2 \%, 0.1 \%$ と順次低調となり，0.05\%以下では殁んど効果が現 われない.

3. Tyrode 液中では胃腺主細胞分泌顆粒の空胞化は 細胞の变㤬に随伴する以外 は殆んよ゙見られない.

4. 充分のヒスタミンを添加すると生体外に於ける胃腺主細胞の退行变性の発 現が遅延する。

5. 膵細胞では生体外に於ける細胞変性が胃腺主細胞に於けるよりも早く現わ れる。

6. ヒスタミンーTyrode 液中では萃細胞にチモーゲン顆粒の新生が見られる。0.3 \%液中で最む顕著であるが, ヒスタミン濃度が減じるに從い低調となる。しかし $0.05 \%$ 液中でもな掿干その活動が見られるが，003\%以下の液中では全く見ら れない.

7. Tyrode 液及びヒスタミンーTyrode 液中ではチモーゲン顆粒の放出を見ない.

8. これらの所見から生体内外を問わずヒスタミン自体が胃腺細胞及び膵細胞 の分泌顆精新生機能を剌戟促進するあのであることが明かである.

\section{References.}

Fujie, K. : On a new gastric hormone, proposed to be named 'productin'. Wakayama Med. Rep. 1 (1953). - Fujie, K. et al. : On the images of endocrine secretory function in the surface cells of the gastric mucous membrane. Arch. histol. jap. 4 (1952). - Cytological studies on the cause of pancreatic secretion. III. Knowleges on gastric hormones. (Jap. with Engl. abstr.) Arch. histol. jap. 3 (1952). - IV. On gastric hormone proposed to be named 'Productin'. (Jap. with Engl. abstr.) Arch. histol. jap. 4 (1953). - V. On the true nature of 'productin'. (Jap. with Engl. abstr.) Arch. histol. jap. 4 (1953). - VI. On the influences of the injection of atropin. (Jap. with Engl. abstr.) Arch. histol. jap. 5 (1953). - Fujie, K. a. T. Esumi : Again on the true nature of 'productin' (Jap. with Engl. abstr.) Arch. histol. jap. 6 (1954). - Fu jie, K. a. T. Suzuki: On the relationship between the temperature of food and the secretion of 'productin'. (Jap. with Engl. abstr.) Arch. histol. jap. 6 (1954). — Fu jie, K. a. T. Kawai : On the relationship between the quantity of food and the secretion of 'productin'. (Jap. with 
Engl. abstr.) Arch. histol. jap. 9 (1955). - Fu jie, K. et al.: Histochemical research on the content in the 'productin' vacuoles of the gastric surface cells. I, II and III. Arch. histol. jap. 13, 15 and 21 (1957, 1958, 1961). - Kasamatsu, S.: Study on the organ preservation. (Jap.) Rinsho-geka 7 (1952). - Machida, H.: Cytological studies of the pancreatic secretion. (Jap. with Engl. abstr.) Kaibo. Z. 25, 26 (1950, 1951). - Nishioka, M.: Studies on the effects of amino acid on the secretory activity of the gastric peptic cells and of the pancreatic cells. I, II. Arch. histol. jap. 17 (1959). - Shimizu, S.: Studies on the effects of histamine upon the secretory function of the gastric gland cells. I, II and III. Arch. histol. jap. 15 and 16 (1958, 1959). - Sugimoto, K. : Study on the secretory ability of the gastric peptic cells and the pancreatic cells in vitro. (Jap. with Engl. abstr.) Shika igaku 23 (1960). 